\title{
2 Economic consequences of globalisation: the Australian framework for reforms
}

\author{
Christopher Findlay, Kostas Mavromaras, \\ and Zhang Wei
}

\section{Introduction}

This paper reviews various elements of the Australian experience of globalisation and its consequences. Australia's experience has many positive elements, but involves challenges, and both are valuable to share in the context of the current debate about the value of international economic integration.

The approach adopted in this paper is to review existing studies, rather than conduct new research. Existing work on relevant topics is synthesised and policy implications are identified.

The focus of this paper is the period since the 1970s, where a significant shift out of an era of protection begins with a policy of significant tariff cuts in 1973 . Section 2 outlines some of the drivers that led to this policy shift.

Section 3 provides more detail on the movement across borders of goods, services, capital, and people. The evolution of Australian policy in these areas is reviewed. The broader context of microeconomic and macroeconomic reform is outlined there too. Some of this material can be put into context by reference to a much longer time period, and in other cases only more recent data are available, or even a snapshot, depending on the scope of existing studies.

Section 4 identifies some of the consequences of these changes in terms of structural change (including labour market adjustment), productivity, and incomes.

The final part of the paper, Section 5, reviews some of the policy lessons and identifies elements of the future reform agenda.

\section{Drivers of change}

Several studies have reviewed the origins of the shift from the 1970s in Australian policy towards globalisation. These drivers include natural circumstances, policy shifts in trading partners, specific events, and the impact of particular people and of ways of thinking.

To place this change in context, Anderson and Garnaut (1987) reviewed the origins of the policy of protection before the 1970s. The motivations were to 
redistribute income towards workers, attract more migrants from Europe in that context, maintain employment especially in import competing sectors, and develop a diversified industrial economy. Banks (2005) (also drawing on Kelly, 1992) explained that Australian policy was part of the 'Australian settlement', which involved using trade barriers to protect manufacturing while employing migrant labour at relatively high wages. These were set Australia-wide by a regulatory body, associated with which was a rigid set of workplace arrangements. Public utilities were created to provide services at 'fair' (but which turned out to be high) prices. Agriculture bore the costs of protection to manufacturing, which led to its own demands for assistance, especially from the less internationally competitive producers. Ergas and Pincus (2016) referred to the 'panoply of schemes', including those to subsidise inputs and to disconnect domestic and international prices. The goal of this system was reflected in the description of 'protection all round' but overall it was 'highly regulated, anticompetitive and distributive' (Banks, 2005, p. 2).

The system was sustained in the early post World War II period by the growth of national income, not generated by manufacturing but by the high-performing agricultural sector. This sector also generated exports required to meet the constraints of an external balance. Its performance was driven by its favourable terms of trade, as well as productivity growth (Ergas and Pincus, 2016), and occurred despite the discrimination against it through the differences in the relative rates of assistance.

Australia had not participated in multilateral tariff reduction negotiations in the 1950s and 1960s under the General Agreement on Tariffs and Trade (Snape, 1984; Adams, Brown, and Wickes, 2013). It had argued a special case on development grounds for not being classified as an industrial country, based on its export mix. Also, its export interests were not included in the scope of the negotiations and dealing with manufacturing tariffs would have been 'unfair' and would have undermined its model of development. As a result, Australia retained very high manufacturing tariffs up to 1970, the highest amongst the so-called 'advanced industrial countries' (Anderson, 2020).

Relative to other economies, Australia's performance started to decline (Anderson and Garnaut, 1987). Australia's world gross domestic product (GDP) per capita ranking dropped from fifth in 1950 to ninth in 1973 and 15th in the late 1980s (Banks, 2005). This decline was the result of 70 years of import substituting industrialisation alongside the other complementary policy measures operating in the labour market, which supported extensive growth (including immigration). It did not support intensive growth, which would have increased productivity and thereby income (Ergas and Pincus, 2016; Anderson, 2020). The policy model was challenged as a result (Berger-Thomson, Breusch, and Lilley, 2018). At the same time, Ergas and Pincus (2016) argued that the regime also provided the foundations that supported the subsequent reforms (for example, the orientation to Asia, the large size of the private sector, access to foreign capital, conservative fiscal policy settings, a narrower base of social transfers, and a role for independent entities in policymaking). 
Another important challenge emerged from the shift in the patterns of Australia's trade, both actual and potential. Australia was naturally resource rich and lightly populated so its main trading partners would always be economies which were heavily populated and resource poor (Anderson, 2020). Initially this was the United Kingdom (UK), and by the late 1940s, half of Australia's imports came from the UK and nearly $40 \%$ of exports went to the UK, with more than $20 \%$ going to other western European countries (Pomfret, 2015). However, the UK in the 1960s began its own reorientation to Europe, finally joining what is now the European Union in 1973. Opportunities in Europe were then denied to Australia through trading arrangements which discriminated against farm exports. Yet they were the bulwark of the 'settlement'.

Following these changes by the UK, the orientation of Australia switched to East Asia, another resource poor and heavily populated region, which had begun to industrialise and to export manufactured products. Mineral discoveries added to the complementarity of Australia and East Asia. Australian policy leaders sought new ways to deepen the integration with the region (Adams, Brown, and Wickes, 2013, ch.3). However, they found that the existing patterns of protection of Australian manufacturing and impediments to migration and investment were inconsistent with doing so. A significant policy shift was required to capture the opportunities, and for mutual benefit both in economic and national security terms. Garnaut (1989) articulated the case for this orientation.

Another factor noted by Corden (1996) was the reinforcement of the standing and capacity of the institution which reviewed and made recommendations on tariff policy (this is now called the Productivity Commission, originally the Tariff Board, which in 1974 became the Industries Assistance Commission). This body operated with transparency and with great effect, taking a focus on national efficiency. Other influences of this type were changes in the ways of thinking, including the translation to Australia of a 'new liberalisation', which emerged from events in other countries. One element was the lack of success of mainly developing countries with the protectionist alternative, and the success of exportoriented growth in East Asia: analysis provided by staff of multilateral agencies reinforced these assessments of failure and success, respectively. Another element was the set of reforms which were also in progress in the 1980s in the UK (under Prime Minister Thatcher) and in the United States (US) (under President Reagan). Anderson (2020) observes that in this context Australia's conservative parties gave up their 'populist and negative opposition' to reductions in protection.

Other events and circumstances contributed to policy change in Australia (Corden, 1996). The Whitlam government (elected in 1972) faced high inflation and a balance of payments surplus, with a fixed exchange rate. There were significant reductions in tariffs in 1973 (of $25 \%$ across the board), a motivation for which was to increase the supply of imports for inflation relief. This was a false start (Adams, Brown, and Wickes, 2013) since there was subsequently a reintroduction of protectionist measures shortly afterwards, linked to the perception of the consequences for employment. However, by 1983, the continuing 
economic crisis (high inflation, high unemployment, large current account deficit, and rising external debt) brought together a variety of other forces for reform. ${ }^{1}$

Finally, Gruen (2009) characterises the strategy of the prime minister (Bob Hawke, ${ }^{2}$ prime minister at the time of the substantial changes in policy, as explained below) as that of 'triangulation'. ${ }^{3}$ The leader in this strategy finds a bundle of policies drawing on both the left and right wings of politics, to create a new bundle that responds to the motivations of all sides of politics and which is also coherent. Because it appeals to the fundamental motivations of a range of opinions, it creates winning political support. An example is the combination of social equity alongside economic liberalism in this period in Australia (Kelly, 2000). Another consequence on this way of thinking was a focus on reaching consensus and taking a gradual approach. As Kelly (2000) explained, there were some 'big bang' events in Australia but generally that method was not followed. The alternative to triangulation presented by Gruen is 'wedge politics', which he says frustrates the development of coherent policy. It may be electorally appealing, but he argues it does not provide the basis for good policy design. He also observes that the lack of a coherent reform strategy in later decades, as discussed below, is linked to the adoption of the strategy of wedge politics.

\section{Policy change}

This section provides more details of the changes in the various elements of policy affecting Australia's experience of globalisation. The indicators show a significant reduction in barriers to merchandise trade, including in highly protected sectors. Foreign direct investment (FDI) flows have also been liberalised, but the degree of restriction on those flows remains high relative to the Organisation for Economic Co-operation and Development (OECD) average. A snapshot of services markets shows they are relatively open compared to the OECD average, although Australian policy is generally more restrictive than the most open regimes in the OECD. Longer-run studies of domestic regulatory reform show a significant degree of reform. The movement of people has also made a significant contribution to the growth of the workforce in Australia. These changes have taken place in the context of a broader reform agenda.

\subsection{Barriers to trade in goods}

Figure 2.1 shows the changes in the rate of protection applied to goods (manufacturing and agriculture) trade since 1903-04 in Australia. The very long-term trend is that of a decline, but with significant spikes in the 1930s and after World War II (see Lloyd, 2008 for a detailed discussion of these events). As noted, there was a significant tariff cut in 1973 which, following a couple of reversals, is sustained from the late 1980s from which time the average rate fell from $10 \%$ for manufacturing and $4 \%$ for agriculture, to $2 \%$ and $1 \%$, respectively. The fall in the rate of assistance to manufacturing closed the gap to the rate applied to 


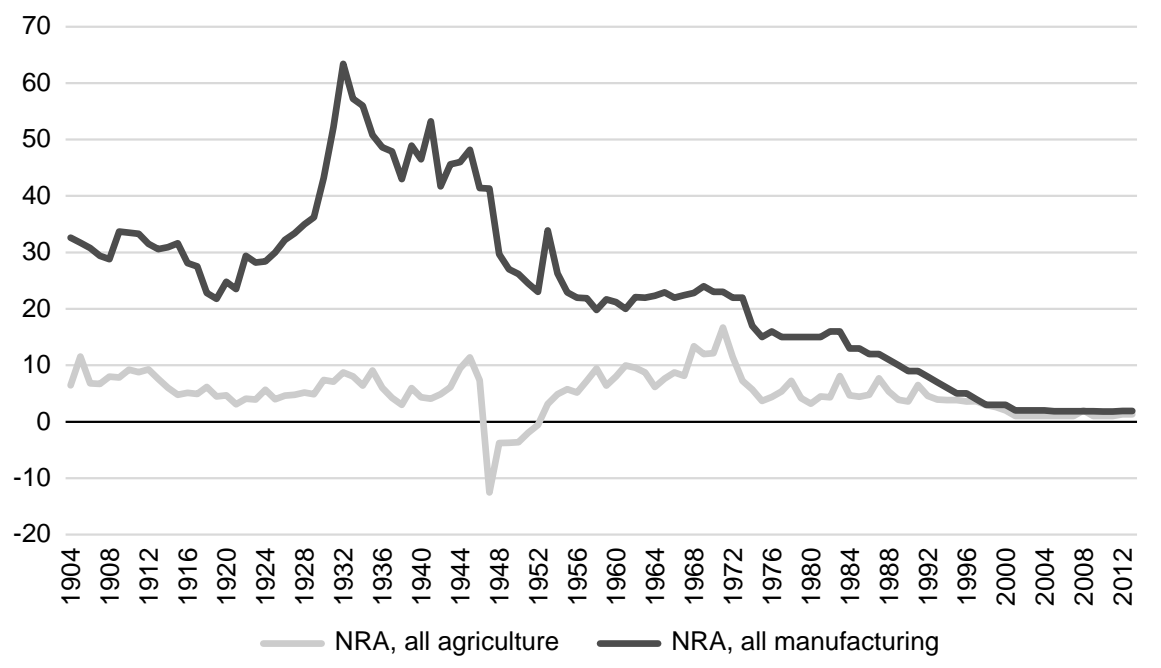

Figure 2.1 Nominal Rates of Assistance, Agriculture and Manufacturing, 1904-2013. Source: Anderson and Aryal (2015), Table A9.

Note: NRA $=$ nominal rates of assistance.

agriculture. Adams, Brown, and Wickes (2013) pointed out these reforms were fundamental to Australia being more active in the multilateral trading system: Australia could be active in the Uruguay Round (from 1986), binding the increasing openness while asking for better market access from others.

The Centre for International Economics (Centre for International Economics CIE, 2017, Box A.1) provides more detail of the changes. Between 1988 and 1992 , all tariffs over $15 \%$ were reduced to $15 \%$ and those between $10 \%$ and $15 \%$ were reduced to $10 \%$. Then between 1992 and 1996 all tariffs were reduced to $5 \%$. Textiles, clothing, and footwear as well as motor vehicles followed their own schedule, falling to at most $5 \%$ by 2015 . Even at $5 \%$, the Productivity Commission (2018a) observed that these tariffs raise costs and reduce the competitiveness of Australian exporters (p. 13). ${ }^{4}$

There is considerable variation in tariff rates at the sectoral level. In 1986, the import weighted average tariff ranged from $0.5 \%$ for forestry products to $89 \%$ for apparel (CIE, 2017). By 2016, this range had narrowed, so that the minimum was $0 \%$ for a number of agricultural products and the maximum was $2.4 \%$ for apparel. ${ }^{5}$

The Centre for International Economics (CIE, 2017) found that trade liberalisation between 1986 and 2016 increased real GDP by $5.4 \%$ (national income by slightly less reflecting the growth of FDI and income transferred offshore). Investment grew by nearly $12 \%$, trade by nearly $30 \%$, and real wages by over $7 \%$. The average family income was about $\$ 8,500$ higher because of liberalisation. ${ }^{6}$

Pomfret (2015) pointed out that in the late twentieth century, apart from its agreement with New Zealand (Scollay, Findlay, and Kaufmann, 2011) and the 
preferences for developing countries, Australia did not discriminate amongst partners. Australia remains a key advocate of the multilateral system ${ }^{7}$ but in the context of its failure to progress, and given the global shift in strategy towards preferential agreements, Australia has mobilised its own strategy. Pomfret (2015) also argued that in an era of low tariffs, other barriers to trade are relatively more important and reform in an international setting becomes connected to (nondiscriminatory) deregulation more generally, a process which is managed in agreements with fewer members. ${ }^{8}$ Adams, Brown, and Wickes (2013) reviewed the debate about the transition to free trade agreements (pp. 116-118) and they refer to motivations for changes, including the value of covering new issues and of responding to events in East Asia, plus business sector pressure. Having signed four agreements in the first decade of the century, Australia has already signed 10 agreements this decade with prospects of more to come. The 'genie was ... out of the bottle' (Adams, Brown, and Wickes, 2013, p. 119). Over 60\% of Australia's two-way trade is covered potentially by these agreements (excluding the Comprehensive and Progressive Agreement for Trans-Pacific Partnership or

\section{CPTPP}

which covers $22 \%$ by itself).

The Asia-Pacific Economic Cooperation (APEC) process was launched in 1989, and its leaders included the Hawke government. Australian economists were also leaders in the design of the process (see for example Drysdale, 2009) and adoption of its principles of open regionalism. The APEC made a critical contribution to the evolution of trade in the region and between the region and the rest of the world, and to Australia's participation in that development (Armstrong and Drysdale, 2009).

A variety of other measures affect trade in goods, including anti-dumping measures. Information in the Global Trade Alert Data Base shows a rise in the use of measures of this (and other) types affecting trade (see also Kirchner, 2018 ). The average duty imposed over the period 2009-15 was $17 \%$, which is high relative to the current maximum tariff of $5 \%$ and the measures applied mainly $(86 \%)$ to the steel industry (Productivity Commission, 2018a).

Industries benefit from budget assistance and tax concessions. Examples of the latter are often cross-cutting, such as those for small business and for research and development expenditure. Expenditure is mostly related to programmes for specific industries. The Productivity Commission (2018a, ch.2) calculates that in 2016-17 these items were $\$ 5.3$ billion and $\$ 7.2$ billion, respectively. The value of tariff assistance was $\$ 6.8$ billion in that year. Allowing for the offset of the effects of tariffs on industry inputs (a cost of $\$ 5.9$ billion) the net assistance to all industry was $\$ 13.4$ billion. The Productivity Commission observes that the bulk of the input penalty from tariffs was borne by the services sector and also by mining while manufacturing was the beneficiary.

The Productivity Commission (2018a) calculated the trend in the effective rate of assistance (the combination of tariff and budget assistance, allowing for the 
input penalty, which is an indication of the change in the ability of an industry to attract resources from the rest of the economy). Agriculture had been disadvantaged by the relatively high rate of nominal assistance for manufacturing. But the effective rate has since fallen to below $5 \%$ for both agriculture and manufacturing.

Anderson, Lloyd, and MacLaren (2007) provided further commentary on the relative rates of assistance to manufacturing and agriculture. The average nominal rate of assistance for agriculture fell from $16 \%$ in the early 1970s, to less than $2 \%$ in the first decade of the 2000s (Figure 2.1). The authors report that no other OECD country other than New Zealand has made such a dramatic change in assistance for agriculture. As they also show, previously there had been a bias against agriculture which was removed as assistance to manufacturing fell. Consumers too benefited from lower prices: they paid an average equivalent of $2 \%$ on food purchases in the decade to 2004 compared to a tax between $23 \%$ and $36 \%$ for the OECD on average (p. 474). Anderson (2020) notes that Australia is one of the few industrial countries that has not increased assistance to agriculture as per capita incomes increased.

\subsection{Services trade and investment restrictions}

There is little data available in consistent terms on trends in policy applying to the services sector. Figure 2.2 reproduces the OECD (2018a) estimates of the services trade restrictiveness index (STRI) for Australia in 2017. The STRI examines policy which affects both competition in domestic services markets and also the ability of foreign providers to enter those markets. Australia has more open services sectors for all but one sector (courier services), compared to the OECD average. Other sectors with relatively high scores (above 0.2 out of 1 ) are air transport, logistics, and accounting. However very few sectors are at the minimum OECD score, the exceptions including rail freight. There are relatively high restrictions on some business services, such as accounting, logistics, courier, and distribution services. The OECD (2018b), in a Trade Policy Brief summarising a more detailed review of Australian policy, observed that there is 'scope for beneficial policy reforms in all sectors' (p. 2). The OECD (2018a) also pointed out that Australia has several cross-cutting (or horizontal) measures that apply to services: these include labour market needs tests, rules on foreigners buying land, restrictions on residency of corporate board members, and costs of obtaining a business visa.

The OECD provides a series of indicators of changes in regulation of various markets (Koske et al., 2015). Table 2.1 shows the values of these indicators for the network sectors, retail, and professional services between 1998 and 2013 (scores can range from 0 to 6 , higher scores are more restrictive). Generally, they show significant declines for Australia. Professional services are an exception primarily due to the higher entry barriers for lawyers. Australia's score in the network sectors is in the bottom three of the OECD. Australia is ranked fifth lowest in retail and sixth lowest in professional services. 


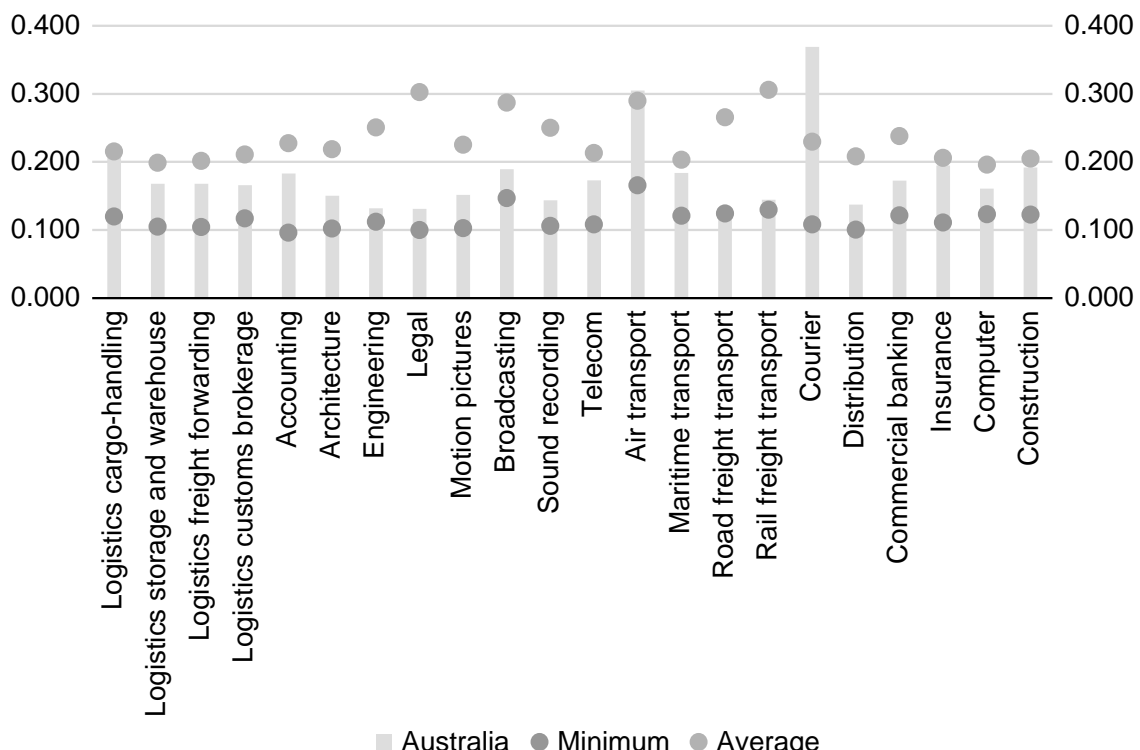

Figure 2.2 OECD Services Trade Restrictiveness Index: Australia, 2018.

Source: OECD (2018a).

Table 2.1 Indicators of Regulation, Australia, 1998-2013

\begin{tabular}{llll}
\hline & Network Sectors & Retail & Professional Services \\
\hline 1998 & 2.24 & 1.44 & 1.58 \\
2003 & 1.98 & 1.35 & 0.79 \\
2008 & 1.60 & 1.35 & 0.79 \\
2013 & 1.50 & 0.70 & 0.92 \\
\hline
\end{tabular}

Source: OECD. Indicators of Product Market Regulation. http://www.oecd.org/eco/ growth/indicatorsofproductmarketregulationhomepage.htm (accessed 22 Oct. 2019).

Ferencz (2019) compiled cross-sectoral measures from the STRI database to estimate an indicator of restrictions applying to digital transactions, which are increasingly important in the services sector. Relevant policies are those applying to infrastructure and connectivity, electronic transactions, payment systems, and other barriers relevant to digitally enabled services. Australia's score is relatively low. However, the principles for the design of policy in this area continue to be debated (Voon and Mitchell, 2019; Findlay, 2019).

\subsection{Foreign divect investment policy 9}

Pomfret (2015) identified different stages of the development of foreign investment in Australia. The first stage involved investment primarily from the US 


\section{Christopher Findlay et al.}

and the UK, to 'jump' the tariff wall. Then followed investment in the minerals sector in the 1960s. Ergas and Pincus (2016) stressed the openness of the economy to capital inflow in the 1950s and 1960s.

A screening process was introduced in 1972 to monitor foreign direct investment and to 'protect' Australian companies if a public interest case could be made for doing so. The rate of rejection of investment proposals rose over the period to the early 1980s. Then a process of liberalisation began, partly driven by the treatment of investment matters in the World Trade Organization and its treatment in Australia's free trade agreements. Armstrong, Reinhardt, and Westland (2017) asked whether free trade agreements are making 'swiss cheese' of Australian policy. The issue became the levels of discrimination amongst trading partners, and China in particular when new criteria related to stateowned enterprises were introduced (Drysdale and Findlay, 2009).

An indicator of the change in the regime applying to inbound foreign investment is the measure of FDI restrictiveness developed by the OECD (with scores out of 1 , higher values indicating a more restrictive regime). For Australia, the index fell from 0.27 in 1997 to 0.15 , indicating a significant change in policy (Table 2.2). But the score for Australia remains high relative to the OECD average (which was less than half that of Australia in 2017). Significant contributors to Australia's relatively high scores are its screening procedures (Thangavelu and Findlay, 2018).

\subsection{People movement regime}

Australia has been a country of migration but its early history is one of discrimination in the sources of the inflows. Since the origin of the country in 1901,

Table 2.2 OECD FDI Restrictiveness Index, Australia and OECD Average 1997-2017

\begin{tabular}{lll}
\hline & Australia & OECD Average \\
\hline 1997 & 0.266 & 0.127 \\
2003 & 0.246 & 0.098 \\
2006 & 0.237 & 0.084 \\
2010 & 0.128 & 0.068 \\
2011 & 0.128 & 0.068 \\
2012 & 0.128 & 0.067 \\
2013 & 0.128 & 0.066 \\
2014 & 0.127 & 0.066 \\
2015 & 0.140 & 0.066 \\
2016 & 0.146 & 0.066 \\
2017 & 0.147 & 0.066 \\
\hline
\end{tabular}

Source: OECD.FDI Regulatory Restrictiveness Index. https://stats.oecd.org/Index.aspx? datasetcode=FDIINDEX\# (accessed 22 Oct. 2019).

FDI $=$ foreign direct investment, OECD $=$ Organisation for Economic Co-operation and Development. 
there were tight constraints on those of non-European descent (Pomfret, 2015). Various events broke down this discrimination, including the experience of World War II, and the acceptance of displaced people. The demand for skills was another driver of change, as was the interest in integration with Asia. But it was not until 1973 that race was removed in formal terms as a factor in migration.

Hugo (2014) referred to the introduction in 1996 of options for temporary migration. Before this, Australia had focussed on permanent migration. Other major changes from this time were the greater attention to the skills of migrants and their distribution across the regions of Australia. Other major changes were removing limits (in 1985) on enrolments of international students, who then had the right to work and later the introduction of visas, which allowed graduates to remain in Australia for employment. The current arrangement allows graduates to remain for 18 months and postgraduates for up to four years (Wright et al., 2016). Another example of more liberal policy is that working holiday visa holders could apply for longer-term visas (up to three years) if they worked for various periods in regional areas. ${ }^{10}$ On the other hand, temporary migration for skilled workers was tightened from March 2018 onwards with shorter visa issue periods, more testing, and less likelihood of leading to permanent residency.

\subsection{Context of microeconomic and macroeconomic reform}

Other policy measures affect the impact of globalisation in Australia. BergerThomson, Breusch, and Lilley (2018) pointed to three waves of reforms. The first wave they say began in the 1970s with the deregulation of the financial sector and led to the floating of the exchange rate and the removal of capital controls in 1983. Foreign banks also then were able to enter the market. Another part of the first phase was an agreement between the government and labour unions, in which unions agreed to limit wage demands while the government undertook to support workers through tax reform, retirement policy, and spending programmes.

The second wave from the mid-1980s included the tariff reforms already discussed. The second wave also included a more decentralised wage bargaining system, which led to a more flexible labour market, which was more able to respond to shocks. Various reforms of regulation and changes promoting competition were also included in this stage. These had the effect of lowering input costs to business, which assisted in the adjustment to the reductions in tariff rates.

Banks (2005) also referred to the interaction of packages of reform, especially in the second phase. Scheduled tariff reductions, as noted above, were introduced from 1988. An important consequence was that the traded goods sector faced more intense international competition. Businesses then pressed not for a reinstatement of protection (reflecting the change in thinking about policy options) but for reductions in input costs, especially in labour markets and utility services' markets. Government policies and institutions were impeding this outcome and Banks says that this situation led to a wide range of domestic reforms in product and factor markets and in the public and private sectors. ${ }^{11}$ 
The third wave according to Berger-Thomson, Breusch, and Lilley (2018) was mainly focussed on fiscal and monetary policy. The key element of interest in this context was the movement to constrain the federal budget deficit, which is important later in the context of a discussion about the sustainability of the tax-transfer system.

\subsection{Trade, capital, and people flows}

Australia's policy settings before the 1970s were anti-trade, and the share of trade in GDP was smaller than might be expected (Anderson, 2020). Following reform, there has been a remarkable reorientation to the world economy.

First, the ratio of exports plus imports of both goods and services to GDP rose from $25 \%$ in 1975 to $42 \%$ in 2016 . However, the traded share of GDP is low compared to the OECD average, which is closer to $60 \% .{ }^{12}$ Guttmann and Richards (2004) argue a relatively low traded share for Australia is to be expected given its location and geography, including its distance from international markets (Pomfret, 2015). Armstrong, Drysdale, and Kalirajan (2008) found that for the period 2002-04, Australia's export performance in terms of meeting its potential exceeds the world average: they also find that Australia exports to East Asia very efficiently (p. 12).

Second, there has been a remarkable redirection of Australian trade, initially towards Japan, which became Australia's largest export market in 1966-67, ${ }^{13}$ then to others in northeast Asia. China became the largest export market in 2009-10 and by 2017-18 accounted for 24\% of Australia's two-way trade. Japan accounted for 10\%, followed by the US, the Republic of Korea, and India. Overall, Asia accounted for 65\% of total trade and Europe for 15\% (Department of Foreign Affairs and Trade DFAT, 2019). The UK share plunged to only 3.5\% of two-way trade, the same share as New Zealand.

Third, another interest is the management of trade and the impact of preferential agreements on trade flows. A study by PwC (2018) using a business survey, reports the utilisation rates in the order of $80 \%$ for merchandise trade in Australia's northeast Asian agreements. Crook and Gordon (2017) using customs data, found lower rates (26\% of total trade or $47 \%$ of eligible trade (p. 11)). They also report considerable variation in utilisation across agreements. Utilisation depends on being able to meet the rules of origin of these agreements, which the Productivity Commission (2018a) advocates be relaxed. The CPTPP, signed in 2018 allows for the accumulation across members in meeting the conditions of the rules of origin and it involves easier administrative processes. ${ }^{14}$ Some countries are referred to in more than one agreement, so traders have decisions to make about which agreement to use. ${ }^{15}$

Fourth, with respect to foreign direct investment, the stock as a ratio to GDP averaged around $13 \%$ in the 1950 s and 1960 s, falling to under $10 \%$ in the 1970 s, but after the reform period grew towards 50\% (Bingham, 2016). This growth is remarkable, but Kirchner (2018) expressed concern that the growth of this ratio has levelled off in the last few years. In terms of FDI flows, Australia attracted an 
inflow of $\$ 62$ billion in 2018 , a $40 \%$ increase on the previous year, which put Australia at number eight in the world as a destination (UNCTAD, 2019). Capital flows into the non-financial private sector in Australia have consistently been of the order of 2\%-3\% of GDP since 1998 (Debelle, 2017, Table 2.1). The world average is $2.3 \%$ and for the Asia-Pacific it is $2.1 \% .{ }^{16}$ The mining sector has become increasingly important as a host of this investment $(2.4 \%$ of GDP in 2014-16 compared to 3.0\% in total). Bingham (2016) reported that Australia's outward FDI was only $1.3 \%$ of GDP on average from the 1950 s to the end of the 1970s. This ratio increased after the reform period, reaching 38\% in 2006-07. Following a decline during the global financial crisis in 2008-09 and then recovery, Australia has had a small net equity position in recent years.

Sales by Australian affiliates offshore are high relative to the gross value of exports. Bingham (2016) quoted a study by the Australian Bureau of Statistics (ABS) in 2002-03 that found that $48 \%$ of the provision of Australian goods and services to the world came from an Australian commercial presence abroad. DFAT (2019), using the statistics of partner countries found for 2015 that Australian-owned affiliates in Canada, the European Union, and the United States had sales of goods and services of about \$124 billion, which was more than double the value of direct exports from Australia to these economies of $\$ 49.4$ billion.

The ratio of affiliate sales to cross-border exports is higher for services (twothirds) than for goods (DFAT, 2018). Bingham (2016) quoted other studies to show that this ratio varies by sector, being high for financial and insurance services, balanced for legal services, and low for education. However, only $40 \%$ of the stock of offshore investment is in the services sector (Bingham, 2018), which is low relative to the world average of about two-thirds. Also, Australia is low in terms of the services share of foreign-owned value-added generated in the home economy (OECD, 2017).

Finally, with respect to people flows, the consequences of the relevant policy changes have been significant. The proportion of Australians who were born overseas in 2016 hit the highest point in over 120 years, with 28\% of Australia's population born overseas (ABS, 2016). That percentage has also increased every year for the last 15 years. About half the Australian population is born overseas or has one parent born overseas (The Guardian, 2017). The growth of migration has made a significant contribution to the growth of the Australian population (Wright et al., 2016, Figure 2.1). It was since 2006 more important than the natural population increase. The main components are classified as economic migrants (Table 2.3), with faster growth in the skilled categories compared to those on working holidays. Migrants arriving since 2012 accounted for $65 \%$ of the growth of the workforce between 2012 and $2017 .{ }^{17}$

The permanent migration programme is expected to be 160,000 per year (previously at 190,000) (ABC News, 2019). On the other hand, the number of temporary visa holders (such as international students and working holiday visits) is much larger than this, and its growth has been relatively fast (Australian Government, 2019). The number of such visa holders in Australia as at June 


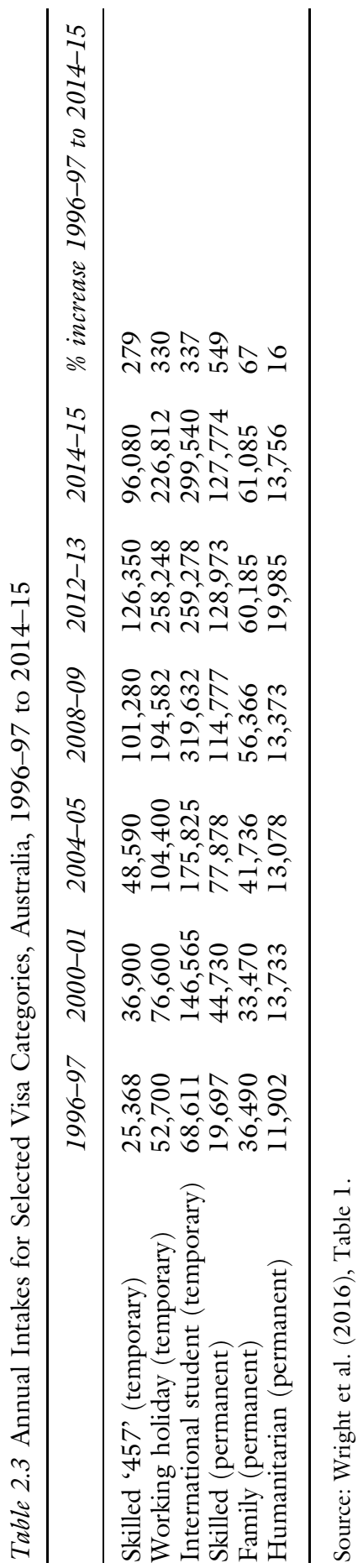


2018 was 878,912 people, which was over 300,000 higher than that numer 10 years earlier, an increase of $54 \%$ over that decade. Students make up about half the number and temporary skilled visa and working holiday visa holders account for about $15 \%$ each.

Another result was a significant change in the direction of migration. The rate of migration from Asia increased, especially after the Vietnam war from 1975. England remains the number one country of origin, but now China and India are ranked two and three (Table 2.4). The main source of growth of temporary visa holders was East and South Asia. China was also the largest source of temporary visa holders, followed by India, then the UK, Nepal, and the Republic of Korea.

\section{Consequences of reform}

Overall, a key indicator of the outcome of this package of reforms has been the growth of the Australian economy, in which there have not been two quarters of negative growth (that is, no recession) for the last 27 years. Australia is now

Table 2.4 Australia's Population by Country of Birth, 2018

\begin{tabular}{ll}
\hline Country of Birth & No. $\%$ \\
\hline England & 992,000 \\
China & 4.0 \\
& 651,000 \\
India & 2.6 \\
& 592,000 \\
New Zealand & 2.4 \\
Philippines & 568,000 \\
& 2.3 \\
Vietnam & 278,000 \\
South Africa & 1.1 \\
Italy & 256,000 \\
Malaysia & 1.0 \\
Scotland & 189,000 \\
All overseas-born & 0.8 \\
Australian-born & 187,000 \\
& 0.7 \\
\hline
\end{tabular}

Source: Australian Bureau of Statistics (2016), '7.3 Million Migrants Call Australia Home', Media Release, 3 April. http://www.abs.gov.au/ausstats/abs@.nsf/Latestproducts/3412. 0 Media\%20Release 12017-18? opendocument\&tabname $=$ Summary\&prodno $=3412.0 \&$ issue $=$ 2017-18\&num $=\& v i e w=($ accessed 22 Oct. 2019$)$. 
the only OECD country with this record, despite a series of external shocks. The drivers of this resilience (Berger-Thomson, Breusch, and Lilley, 2018) are the packages of reforms outlined so far, including with respect to migration, as well as the flexibility of the exchange rate, the flexibility of the labour market, fiscal management, and monetary policy parameters.

Another driver of performance has been the shift in the terms of trade (Figure 2.3). There had been a long decline in Australia's terms of trade from the early 1950s. This trend turned around from 2003 until 2011, with rising demand from China for resources. This boom had many important consequences, which are also outlined below, including the ability to sustain reform. The following sections discuss several more specific indicators of the performance of the Australian economy.

\subsection{Structural change}

The reforms have been associated with a significant change in the structure of the economy. The share of manufacturing in GDP by 1960 was about the same as the OECD average, although Australia's relatively low population meant that it could not have a strong comparative advantage in that sector (Anderson, 2020). Since the first tariff cut in 1973 , the share of manufacturing fell from $16 \%$ to close to 6\% by 2017-18 (Berger-Thomson, Breusch, and Lilley, 2018, Chart 6; see also Figure 2.4).

The services sector share of output grew to over $70 \%$ by 2016 . Adeney (2018) highlights the growth of the business services sector (Figure 2.4). This is part of a process in Australia in which domestic supply chains have become more

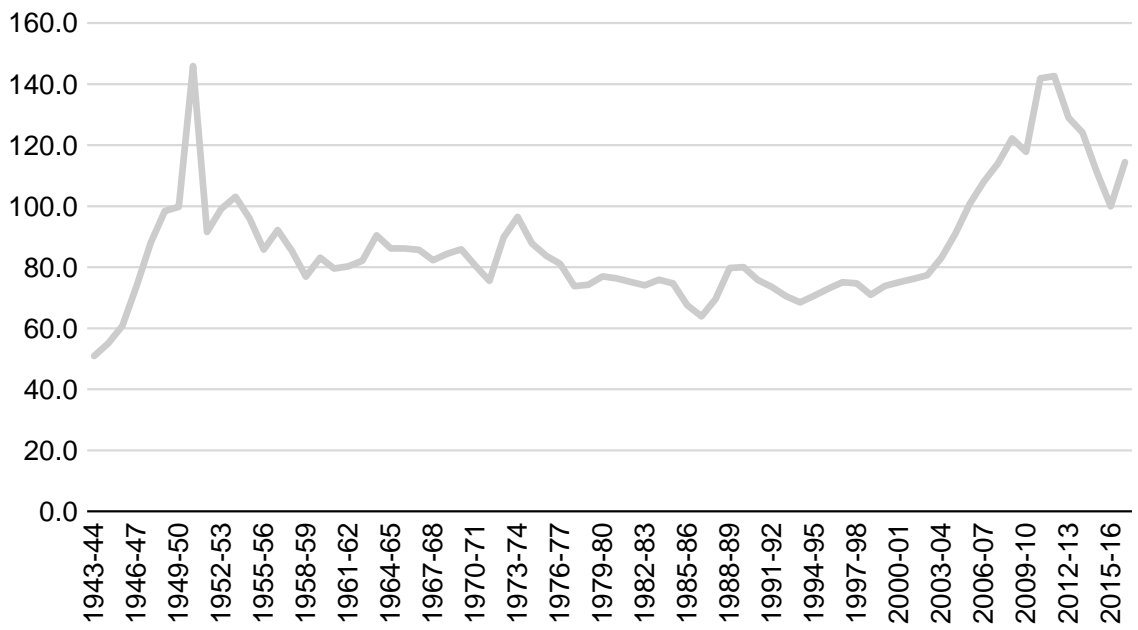

Figure 2.3 Terms of Trade, Australia, 1943-44 to 2016-17 (2015-16 = 100).

Source: Australia's Trade and Economic Indicators. https://dfat.gov.au/trade/resources/ trade-statistics/Pages/trade-time-series-data.aspx 


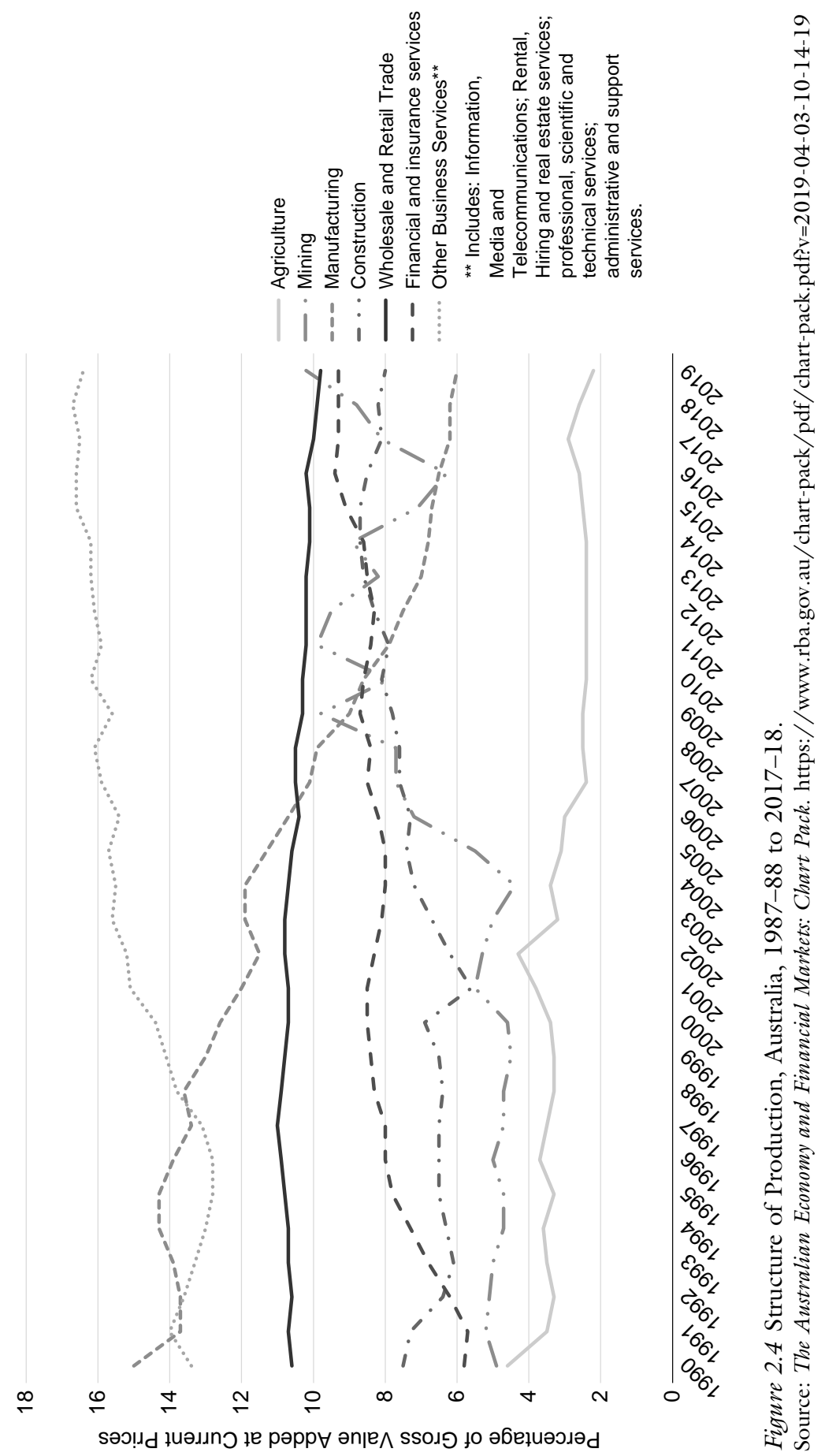


fragmented and where various sectors are located. This process is especially evident in goods production since the first tariff cut of 1973 (Adeney, 2018, Graph 5). It is also an Australian example of 'servicification', which others have observed (Lodefalk, 2015).

Anderson (2018) examined the question of why the agricultural sector has been so resilient, with a long period up to the $1950 \mathrm{~s}$ where it continued to account for $20 \%-30 \%$ of output and then in the recent period when (at a much lower share) it was far less relatively affected by reform than manufacturing. First, Anderson pointed out that agricultural prices rose almost as much as mineral prices. Second, other factors were reductions in trade costs, good investment in and returns to spending on research and development. The flexible exchange rate also meant that the economy could adjust more smoothly to the resource boom without a rise in inflation, which would have been more disruptive. Third, Australian resource endowments matter, since there is a relatively large endowment of land in the country.

The growth of trade and structural change combined to produce significant shifts in the composition of Australian exports, although less so with respect to imports (Anderson, 2014). Up to the early 1980s, exports were dominated by wool and wheat - Australia 'rode on the sheep's back' (Cashin and McDermott, 2002). From the 1970s, there was a shift to minerals and fuel exports, originally iron ore and coal, and later gas. From the 1980s, services exports became more significant, particularly tourism and education. For a long period, imports were dominated by capital goods, but as tariffs were cut consumer goods imports increased, also reflecting a rise in their quality as a result of access to international markets. ${ }^{18}$ Tourism imports also increased.

The adjustment within the previously relatively highly-protected manufacturing sector has been a topic of interest. In a study of the period since 1990, ANZ (2017) found that exports of processed primary products grew by (about) a factor of 5 , elaborately transformed manufactured (ETM) goods by a factor of 3 (including the value of re-exports), and simply transformed manufactured (STM) products by a factor of 2 (but with little change since 2000). ${ }^{19}$ The composition of these changes aligns with expectations based on Australian resource endowments, but the growth is relatively slow: over the same period Australia's total exports of goods and services grew by more than six times.

The growth of ETM exports might be an indicator of an increase in Australia's participation in global value chains. But in relative terms, Australia's global value chain participation remains low, in terms of forward and backward linkages, and lower than any other OECD country in terms of the foreign value-added share of exports, in part due to Australia's location at the start of the value chain for most products (e.g. mining) and its distance from potential foreign suppliers. ${ }^{20}$ 


\subsection{Labour market adjustment programmes}

The structural change of the Australian economy in the recent decades driven by globalisation has significant impacts on the labour market. Displaced workers from the declining firms and sectors must move to the expanding ones. Australia has mainly relied on a flexible labour market during this labour movement process and thus it is common that displaced workers receive limited public support in transiting to new jobs. However, displaced workers in certain sectors and regions have access to special support through various labour adjustment programmes (LAPs), which operate within the broader structural and regional adjustment programmes (OECD, 2016). These programmes aim to support affected workers, businesses, industries, and regions through a time of change. Support has been provided to a diverse range of sectors, but most expenditure and programme effort has been concentrated in the manufacturing (the automotive industry and the textile, clothing, and footwear industry) and agricultural sectors.

Beer (2015) reviewed structural adjustment programmes in Australia between 2000 and 2012. During that period, 135 structural adjustment programmes were operating, with the total value of commitments over $\$ 80$ billion of prospective outlays, the vast majority of which was federal expenditure. The scale of funding varies substantially across programmes. A few of them are enormous. For instance, The Dairy Structural Adjustment Program had a total budget of $\$ 1.63$ billion and the Automotive Competitive investment Scheme was budgeted for $\$ 7$ billion. It is more common that a programme costs between $\$ 5$ million and $\$ 500$ million. There are also programmes which are very small. ${ }^{21}$

LAPs are a crucial component of structural and regional adjustment assistance in Australia. LAPs are designed to assist displaced workers transition to new jobs during a plant closure or economic shock. Until July 2015, retrenched workers in the sectors of the automobile industry, textile, clothing and footwear, steel and the forest industry in Tasmania had been offered automatic access to the LAPs. In addition, four new programmes have been recently established for displaced workers in four companies. ${ }^{22}$

Some reviewers argue that the LAPs work well. Beer (2015) identifies the benefits of the LAPs to workers and to regions. Others are more critical. Daley and Lancy (2011) found that these programmes only include a modest amount of funding for job search and training assistance for directly affected workers. They further suggest that these programmes have a high cost per job (the one-off cost per expected job from structural adjustment programmes ranges from $\$ 20,000$ to $\$ 60,000$ ), do not have a significant effect on long-term employment trends and do not lead to better performance than other regions that lose a major employer but without government assistance. Daley and Lancy (2011) only focused on the direct labour market outcomes of affected workers while Beer (2015) considers both social and economic outcomes.

The OECD (2016) also criticised the LAP programmes in Australia mainly for their limited coverage compared with the overall figure of displaced employees in 
Australia. It is suggested that the total number of employees possibly concerned by the LAPs is less than $1 \%$ of total employees in Australia, while on average 2.3\% of employees with tenure of at least one year were displaced each year over the period 2002-13. Other OECD countries have programmes with wider coverage (e.g. the Trade Adjustment Assistance programme in the United States). The OECD report also suggests that the services provided through the LAPs could be improved by aiding displaced workers occur earlier and offering better training.

O'Neil (2014), based on the experience of adjustment in a regional city in South Australia, argued that the most important component is the provision of training for the development of human capital. The Productivity Commission (2014) reviewed the global context and Australian policy changes that led to the demise of the automotive industry, which occurred by the end of 2017 (Beer, 2018). The Commission stressed that decades of transitional assistance had forestalled but not prevented the closure of the industry. It observed that in the order of 40,000 people would lose their jobs over the transition period, compared to about 355,000 that had been retrenched in the year to February 2013 in all sectors. In other words, labour market processes were accommodating much larger adjustments in aggregate. The Commission noted that the costs of adjustment may be higher for workers retrenched from this industry (as noted by the Australian Government, 2014) and that the costs could be regionally concentrated. But the Commission argued that regional adjustment funds and industry specific programmes were inefficient and an inequitable way of providing support. The generally available 'welfare, training, and employment services' should be used.

\subsection{Productivity}

Labour productivity growth is linked to growth in wages and incomes, and therefore is a key channel by which the benefits of globalisation are distributed. The drivers of labour productivity growth include capital deepening and multifactor productivity growth, the latter indicating the effects of changes in technology and of economic efficiency. Both capital deepening and multifactor productivity (MFP) growth are affected by exposure to globalisation.

The Productivity Commission (2017a; 2019, Table 1) decomposes the growth of labour productivity from 1973 to 2018 in these two sources. Over that period, MFP growth accounts for about $40 \%$ of labour productivity growth. The exceptions are firstly in the 1990s, when MFP accounted for two-thirds of the growth. The other is the period since 2003 when MFP growth had been zero or small, at least up until 2011-12 (see also Campbell and Withers, 2017). ${ }^{23}$

The shift in the contribution of MFP growth before, during, and after the 1990s is also a feature of other OECD economies (Mann, 2016; Productivity Commission, 2019). Various explanations are offered for the slowdown, which preceded the global financial crisis. There appears to be a paradox since this slowdown has occurred alongside the emergence of new technologies. 
Crafts (2018) concluded the issue is not a result of measurement errors. He expects powerful effects of new technologies but with a lag. In any case, the commentators (e.g. Mann, 2016) focused on the contributions of the government to resolving the slowdown, which is the interest here with respect to the Australian experience.

The starting point is to examine the link from reform to productivity and the rise in productivity in the 1990s compared to the earlier period. Kent and Simon (2007) found that reforms have a consequence for productivity in later years. The Productivity Commission (2017a) also argued that there is a link between the performance of the 1990s and the earlier reforms, but that this effect should be considered in conjunction with the impact of the application of information and communication technology (ICT). However, access to ICT may itself be a consequence of the openness of the economy. The productivity growth of the 1990s, the Productivity Commission reports, was led by the application of this technology in the services sector, which also depended on the performance of input-supplying services sectors like telecommunications, which also underwent reform. Anderson, Lloyd, and MacLaren (2007) also concluded that the reduction in assistance to agriculture has been associated with a rise in farm MFP.

Participation in trade, which followed reform, is a driver of productivity, through learning by doing channels and market size effects, for example. Using firm-level data for Australia, Tuhin, and Swanepoel (2017) found that exporters generally are larger than non-exporters and will have grown faster than nonexporters. They also find that exporting increases labour productivity and the average wage paid by exporters, and that exporting increases the chance of business survival. Trade (and factor movements, see below in this section) provides access to technology and the competition associated with trade adds to the incentives to innovate.

Firm-level selection and performance in open markets will also drive sectoral productivity growth. For example, as new international markets become available due to liberalisation, relatively more productive firms are attracted to exporting (they can more easily cover the set up costs of doing so), more productive firms then also expand, and less productive firms contract (Melitz, 2003). This will change productivity measured at the sectoral level, and should also lead to a reduction in the degree of dispersion of productivity amongst firms in a sector. ${ }^{24}$ Anderson, Lloyd, and MacLaren (2007) also suggested that the Melitz effect of raising average productivity and narrowing its dispersion applied in agriculture, and contributed to better export performance by some sub-sectors, which reinforced the commitment to openness.

There are other observations contrary to the Melitz outcome. One of the explanations of the slowdown in productivity is the survival of 'zombie firms', which means the Melitz effect has not been as effective as otherwise. Various explanations are offered, including conditions in the financial sector (especially banking) and insolvency regimes. Quinn (2019) reported that the Australian technological frontier has not kept up with the global frontier (except in the mineral and energy sectors) and that amongst laggard firms, productivity has not 
improved. The Productivity Commission (2019, p. 47) also noted the dispersion across productivity levels amongst Australian firms and promotes the concept of improving the diffusion of existing technologies and knowledge.

FDI is important for growth, through its contribution to the capital stock and in mining in particular. Through the transfer of technology and the promotion of competition, FDI can also have the effect of adding to productivity in the domestic economy. Another channel is the transfer of the income and experience generated by offshore investment (which as reported is of a similar magnitude to the domestic stock).

Parham et al. (2015) discussed the ways in which migration, also a source of growth in terms of the labour force, might contribute to productivity. The channels they identify are the selection of migrants, policies that affect the work of migrants after their arrival, and the broader environment that affects the connectivity of the migrants with others. They found positive effects on productivity from changes in policy relevant to these matters. They also found that migrants have been more productive (according to earnings) and have increased their productivity faster than non-migrants. They note that migration has played an important role in meeting the requirements for various skills.

Structural change, also driven by globalisation, combined with different productivity levels between expanding and declining sectors, could be an important explanation for the change in overall productivity growth rates. The Productivity Commission (2107b) highlighted the structural change towards the services sector, which it asserts has a lower level of productivity, and which might thereby reduce labour productivity growth in future. Campbell and Withers (2017) on the other hand concluded that there is 'little cause for alarm over the effect of structural change' since the productivity levels in the services sector are similar to all other sectors of the economy. Adeney (2018) suggested that the reorganisation of production processes in Australia, and the lengthening of supply chains, including the processes of contracting, generate gains for productivity.

Several factors have been linked to this slowdown in MFP growth in Australia, especially up until 2011-12, which has contributed to the lower labour productivity growth. These include the effects of drought on productivity in agriculture and an acceleration of the use of inputs which preceded the growth in output. The growth in inputs followed from increased profits in the past and expectations of further increases (Parham, 2012). An example is the construction phase in the mining boom; however the mining sector was not the only factor.

Another explanation is that the effects of the reforms were significant but also exhausted or that reform fatigue and backtracking have set in. The Productivity Commission (2017a) reported that productivity levels in Australia are below the frontier observed in the same sectors in other economies (see their Figure 2.10, where only for an aggregate of mining, agriculture utilities, and construction is Australia at the frontier). Further improvements are possible. The Productivity Commission said there is a clear role for a policy change to close this gap. A similar point was made by the OECD in relation to the services policy. Garnaut $(2005,2013)$ argued that there is substantial scope for reform. 


\subsection{Inequality}

The next question is how the developments in industry structure and productivity feed into income inequality in Australia. Leigh (2013) identified a process of a 'great compression' of income distribution (ch. 2) in Australia from the 1920s to the 1970s, which was also observed in other economies, and a 'great divergence' (ch. 3) from the 1980s until now. Over that time the share of what Leigh calls the affluent and the opulent doubled from $6 \%$ to $12 \%$. Australia is now twice as unequal as it was in the 1980s, according to these data. But Leigh also points out that the US is twice as unequal as Australia, and that in Australia over this period those at low- and middle income-levels have all gained, although those at the top have gained by more.

The Productivity Commission (2018b) reported that while incomes in Australia rose in every decile in the last 27 years, the Gini coefficient related to market incomes has increased. The Commission then also found that the tax system, which is progressive and the transfer system which is highly targeted has offset this increase (reducing the Gini coefficient by $30 \%$ ). The Commission noted, however that the application of these measures may have had effects on the supply of labour. Households in Australia also receive in-kind transfers from the government in health, education, housing, and childcare. Considering these, the Gini coefficient is lowered by another $30 \%$. The Commission concluded that policies and institutions can affect the levels of inequality. However, the Productivity Commission (2017a) also expressed concern that the growth of the social insurance system is $20 \%$ faster than the growth of GDP, which suggests there is a risk that it will be difficult to maintain. Leigh $(2013$, ch.4) argued that, allowing for tax-transfer systems and the provision of services, developments in 'technology and globalisation' contribute about one-third of the divergence in incomes (other factors include a fall in the degree of unionisation of the work force, cuts in taxes, and the provision of education services).

Apart from taxes, transfers, and in-kind transfers, the Commission also discusses the role of policies for specific issues. For example, the Commission noted the movement of people through deciles of the income distribution in the course of their life, but reports that some are stuck and remain 'entrenched'. About $3 \%$ of households remain in the lowest two deciles over their lifetime. The Commission discussed measures relevant to these groups, related to health and housing. One of Leigh's (2013) concerns was that higher inequality slows down social mobility (ch.6).

\section{Conclusion}

In the manufacturing, agriculture, and several services sectors, policy reform in Australia has been significant. Issues remain with respect to some services sectors and to factor flows. These changes are associated with outcomes that have been significant in terms of indicators of the openness and growth of the economy, the direction of trade, and the structure of output and trade. At the same time, the perception of the community to trade appears to be positive. ${ }^{25}$ 
Banks (2005) drew lessons from this experience. First, he argued that 'external liberalisation' is a good place to start reform. This might be contrary to expectations, based on the idea that improving domestic efficiency first is important to help adjust to a change in external openness but in Australia, the latter drove the former.

Banks' second observation was that Australia reformed unilaterally in the 1980s, not in exchange for market access offered by trading partners. Partly, as both he and Corden (1996) explained, this was because the multilateral system was not initially dealing with markets of interest to Australia, which then had to consider the nature of the gains from reform regardless of the actions of others.

The third observation by Banks was that reform in Australia was not a 'big bang' approach but an incremental one. It was also a programme that was wideranging. The experience of the original $25 \%$ tariff cut might have influenced the design of the later programme, he proposes. He suggested that the approach adopted brought about the benefits that might have been found in the big bang approach but without the costs. It was important that losses from reform in some sectors were offset by benefits to that sector from reform in others. ${ }^{26}$ Specific measures were, however, introduced into the most sensitive sectors. There were also examples of direct compensation for losses due to reform and regions where costs of reform were concentrated were also supported.

Fourth, Banks stressed two institutional reforms. They were designed to promote and sustain reform, to build wider community support, and to offset the influence of private interests in the design of policy. These were the reliance on the role of the Productivity Commission and the adoption of a framework for competition policy, which applied across the whole economy. Banks linked the use of these institutions and the design of their processes and systems to the response to obstacles to reform including its diffuse benefits, the lack of incentives for winners to mobilise to support reform, bureaucratic constraints, and multiple jurisdictions.

Banks' final observation was that while political leadership is critical for reform (see the earlier discussion of triangulation, for example), 'its most enduring legacy' may be to entrench the right institutions.

Anderson, Lloyd, and MacLaren (2007) provided a more specific case of how policies across sectors matter. For example, the cuts to assistance for nonagricultural sectors was important for the success of the reforms of agriculture. They said other microeconomic and macroeconomic reforms made it easier for farmers to adjust and to raise their productivity. Farmer resistance to reform in their own sector was thereby reduced.

Lloyd (2008) discussed the experience of the 1973 reductions in tariffs and the longer-term changes dating from the late 1980s. The lesson he takes from those experiences is that phased reductions can work, since they apply across the board and they occur each year, which helps to maintain momentum and predictability. Corden (1996) also made the point that the operation of tariff systems based on clear principles are less likely to be eroded by private interests and lobbying. The commitment to reform and the nature of the policymaking process also meant 
that lobbying for special assistance was made less worthwhile in the reform period (Anderson, 2020).

The reform agenda is not over, and a number of issues are identified in the material reviewed here. The drop in productivity growth in the 2000s was also highlighted, and Australian per capita incomes continuing to grow in spite of that development as the terms of trade improved. Garnaut (2013) identified a great complacency in Australia and argued for further reform to sustain productivity growth. The culture of policymaking in this respect, however, demands constant attention, he said. Garnaut's (2013) assessment is that in this century the role of private interests in policymaking has increased. Garnaut (2018) also argued that

we will not get back to policy-making in the public interest without reform to reduce the influence of vested business interests in the political process, to strengthen independent centres of policy research, and to nurture a more competitive and better resourced media.

There are many issues now worthy of attention for policymaking in the public interest. Barriers at the border remain important. For example, the scope of the services sector issues that might be addressed is evident in the discussion of policy in Australia in that sector. For agriculture, although writing a decade ago, Anderson, Lloyd, and Maclaren (2007) identified priorities that remain relevant, including reviewing import restrictions applied on the grounds of human health, removing remaining restrictions on the use of genetically modified varieties of farm products, and the adoption of more efficient water pricing policies. In manufacturing, items for attention include the use of the anti-dumping system and the removal of remaining tariffs (as well as binding them). New issues will continue to emerge as technology changes and world markets evolve; already restrictions related to data flows are more prominent. With respect to factor flows, significant degrees of discrimination remain in investment policy and elements of migration policy have been tightening.

A feature of the Australian approach to reform as noted already has been its wide-ranging coverage. Attention to barriers to international engagement remains important but according to the Australian experience doing so in the context of a package of reforms will be more effective (that is, the outcome will be more extensive and more likely to be sustained). Examples are the following.

- The Productivity Commission (2017b) developed a new agenda for microeconomic reform more generally, which includes attention to the health and education systems, to the performance of cities (including the management of infrastructure projects and land use), energy markets, and the innovation ecosystem, as well as the relationships between federal and state governments.

- Garnaut's action list (2013, ch.6) included firstly a focus on competition, including audits for monopoly power and high profit margins and reviews of 
pricing of natural monopolies in utilities, airports and roads. His second main area was barriers to international transactions. His third main area was taxation reform.

\section{Notes}

1 Anderson (2020) and Brennan and Pincus (2002) presented different views on the positive and neutral contributions (respectively) of key economists to the implementation of reform.

2 Bob Hawke died in May 2019. For another assessment of the elements of success of the Hawke government reforms, see Adam Creighton (2019), 'He Came, He Saw, He Fixed the Economy', The Australian, 18-19 May, p. 41. https://www. theaustralian.com.au/inquirer/he-came-he-saw-he-fixed-the-economy/newsstory/60a50bl64d3aa9875lela6bfl3fb33b5

3 This concept is attributed to President Clinton adviser Dick Morris. See https:// politicaldictionary.com/words/triangulation/

4 The World Trade Organization in its trade policy of review of Australia in 2015 stresses that these tariff reductions have not been bound and that there is a significant gap between applied and bound rates (World Trade Organization WTO, 2015).

5 As Treasury says, 'Over recent decades the importance of tariffs as a revenue source has declined dramatically. This is expected to continue into the future.' Its share in total tax revenue was of the order of $2 \%$ by $2008-09$, compared to $6 \%$ in 1973-74. See Australia's Future Tax System, ch E. http://taxreview.treasury. gov.au/content/FinalReport.aspx?doc=html/publications $/$ Papers $/$ Final_ Report_Part_2/chapter_e8-3.htm

6 Dollar values in this paper refer to Australian dollars.

7 See for a recent example the speech in September 2018 by the Secretary of the Department of Foreign Affairs and Trade. https://dfat.gov.au/news/speeches/ Pages/defending-the-rules-based-trading-system-the-role-of-business.aspx

8 The Productivity Commission continues to argue for precautions in the application of a preferential strategy - see section 5.2 of Productivity Commission (2018a). See also Armstrong (2012).

9 This section concentrates on barriers to direct investment. See Thangavelu and Findlay (2018) for a more detailed discussion of issues related to portfolio flows of capital.

10 A significant number of people also breach their visa conditions and stay in Australia longer than originally approved, estimated to be about 63,000 in 2017. See Australian Migration Statistics 2016-17.https://data.gov.au/data/dataset/ australian-migration-statistics/resource/9e5ffab9-81dd-4e34-81b4-

7la920da4d98 (accessed 22 Oct. 2019), Table 4.0. See also Australian Government (2019, pp. 24-25).

11 Banks (2005) in Box 1 summarised the reforms in tariffs, capital markets, infrastructure, labour markets, human services, competition policy, macroeconomic policy, and taxation.

12 OECD Data. Trade in Goods and Services. https://data.oecd.org/trade/tradein-goods-and-services.htm\#indicator-chart (accessed 22 Oct. 2019).

13 Dates in this format refer to Australian financial years, which start on 1 July and end on 30 June.

14 See White and Case (2019). Some commentary however is that the selfcertification process, which the CPTPP offers will also create different risks for business. See Pitcher Partners (2018). 
15 The Department of Foreign Affairs and Trade provides a portal to free trade agreements: https://ftaportal.dfat.gov.au/ (accessed 22 Oct. 2019).

16 World Bank, Foreign Direct Investment, Net Inflows (\% of GDP). https://data. worldbank.org/indicator/BX.KLT.DINV.WD.GD.ZS (accessed 22 Oct. 2019).

17 Australian Government, Australian Migration Statistics, 2016-17. https://data. gov.au/data/dataset/australian-migration-statistics/resource/9e5ffab9-8ldd4e34-81b4-7la920da4d98, Table 7.0 (accessed 22 Oct. 2019).

18 See examples presented by DFAT (clothing, footwear, motor vehicles, household appliances, and audio visual equipment) at https://dfat.gov.au/trade/resources/ publications/Pages/benefits-of-trade-and-investment.aspx (accessed 22 Oct. 2019).

19 According to the ABS: 'STM consist mainly of basic metal manufactures, chemicals and other intermediate manufactured goods which will be used as inputs into other goods. Examples include flat-rolled steel products, chemicals, leather and cotton yarn. ETM are generally what would be termed 'finished goods'. ETM covers a vast range of goods, including machinery, whitegoods and other household wares, motor vehicles, clothing and footwear.' See https://www.abs. gov.au/ausstats/abs@.nsf/Lookup/by\%20Subject/5489.0 2015 Main \%20Features Trade\%20Import\%20and\%20Export\%20Classification 10029

20 OECD/WTO Trade in Value-added Database (TIVA): Australia. http://www. oecd.org/sti/ind/TiVA\%20Australia.pdf

21 Examples of mid-size programmes are the Moreton Bay Marine Park Structural Adjustment Package (\$15.1 million), the Structural Adjustment Fund for South Australia ( $\$ 45$ million from the Commonwealth and $\$ 10$ million from the State), the Illawarra Advantage Fund (\$10 million), and the Regional Food Producers Innovation and Productivity Program (\$35 million). With respect to small programmes, two individuals received assistance of around $\$ 50,000$ as a result of the creation of Marine Protected Areas in Tasmania.

22 Alinta Energy is an Australian electricity generating and gas retailing company with around 700 employees. In May 2016, it permanently closed Playford A Power Station, Playford B Power Station, and Northern Power Station in South Australia. Arrium was an Australian mining and materials company. The company employed nearly 10,000 workers. In April 2016 the company went into voluntary administration with debts of more than $\$ 2$ billion. In September 2017, it was acquired by British-owned GFG Alliance. Caterpillar is a mining equipment manufacturer. In 2015, it closed its north-west Tasmanian factory, making 280 workers redundant as it moved to its new facility in Thailand. Queensland Nickel is a company owned by businessman and former politician Clive Palmer in the sector of refinery. In January 2016 the company entered into voluntary administration. In April 2016, the company's creditors voted for liquidation.

23 See Parham's website (http://www.deanparham.com/australia-s-productivitytrends/recent-developments) for a discussion of the growth and then decline of MFP growth since 2011-12 and also the collapse of labour productivity growth in recent years (negative in 2017-18: Productivity Commission, 2019).

24 Various explanations are offered, including conditions in the financial sector (especially banking) and insolvency regimes. See http://www.oecd.org/eco/ growth/exit-policies-and-productivity-growth.htm.

25 Lowy Institute. 2017 Poll. https://www.lowyinstitute.org/publications/2017lowy-institute-poll

26 An important contribution by the Productivity Commission and its predecessors was investment in general equilibrium modelling methodologies which could be used to capture the significance of reform at the industry and regional levels. See Anderson (2003) and Dixon (2008) for a discussion of these contributions. 


\section{Christopher Findlay et al.}

\section{References}

ABC News (2019), 'Scott Morrison's Population Plan Aims to Draw Migrants to Country Towns to Ease Congestion', 20 March. https://www.abc.net.au/news/ 2019-03-20/scott-morrison-population-plan-migration-program/10921258 (accessed 22 Oct. 2019).

Adams, M., N. Brown, and R. Wickes (2013), Trading Nation: Advancing Australia's Interests in World Markets. Sydney: UNSW Press.

Adeney, R. (2018), 'Structural Change in the Australian Economy', Bulletin, March, Reserve Bank of Australia.

Anderson, D. (2014), Fifty Years of Australian Trade. Canberra: Department of Foreign Affairs and Trade. https://dfat.gov.au/about-us/publications/ Documents/fifty-years-of-Australias-trade.pdf (accessed 22 Oct. 2019).

Anderson, K. and R. Garnaut (1987), Australian Protectionism: Extent Causes and Effects. Sydney: Allen and Unwin.

Anderson, K. (2003), 'International Trade and Industry Policies', in I. McAllister, S. Dowrick, and R. Hassan (eds), The Cambridge Handbook of Social Sciences in Australia. Cambridge: Cambridge University Press, pp. 168-185.

Anderson, K. (2018), 'Mining's Impact on the Competitiveness of Other Sectors in a Resource-rich Economy: Australia Since the 1840s', Mineral Economics, 31, pp. 141-153.

Anderson, K. (2020), 'Introduction and Overview', in K. Anderson (ed.), World Scientific Reference on Asia-Pacific Trade Policies: Volume 2: Agricultural and Manufacturing Protection in Australia. Singapore: World Scientific.

Anderson, K., P. Lloyd, and D. MacLaren (2007), 'Distortions to Agricultural Incentives in Australia Since World War II', The Economic Record, 83(263), pp. 461-482.

Anderson, K. and N. Aryal (2015), Australian Grape and Wine Industry Database, 1843 to 2013, Wine Economics Research Centre, University of Adelaide. https:// www.adelaide.edu.au/wine-econ/databases/winehistory/(accessed 30 Oct. 2019).

ANZ (2017), 'Australian Made', Infocus, May. https://bluenotes.anz.com/ content/dam/bluenotes/documents/ANZ_Manufacturing_AustralianMade.pdf

Armstrong, S. (2012), 'Australian Trade Policy Strategy Contradictions', The World Economy, 35, pp. 1633-1644.

Armstrong, S.P. and P. Drysdale (2009), 'The Influence of Economics and Politics on the Structure of World Trade and Investment Flows', East Asia Bureau of Economic Research Working Paper, No. 61.

Armstrong, S.P., P. Drysdale, and K. Kalirajan (2008), 'Asian Trade Structures and Trade Potential: An Initial Analysis of South and East Asian Trade'. Paper presented at the Conference on the Micro-Economic Foundations of Economic Policy Performance in Asia, co-hosted by NCAER and EABER, 3-4 April, New Delhi. https://crawford.anu. edu.au/pdf/phd/armstrong/s3pl.pdf (accessed 22 Oct. 2019).

Armstrong, S., S. Reinhardt, and T. Westland (2017), 'Are Free Trade Agreements Making Swiss Cheese of Australia's Foreign Investment Regime?', International Journal of Public Policy, 13(3-5), pp. 290-303.

Australian Bureau of Statistics (2016), 'Overseas Born Aussies Highest in Over A Century’, Media Release. http://www.abs.gov.au/ausstats/abs@.nsf/lookup/ 3412.0Media\%20Release12014-15 (accessed 22 Oct. 2019). 
Australian Government (2014), Growing Opportunities: South Australian and Victorian Comparative Advantages. Report of the Panels for the Reviews of the South Australian and Victorian Economies. Canberra: Department of Industry.

Australian Government (2019), Report of the Migrant Workers' Taskforce. Canberra: Commonwealth of Australia.

Banks, G. (2005), 'Structural Reform Australian-style: Lessons for Others?' Presentation to the IMF, World Bank, and OECD, May. https://www.pc.gov.au/ news-media/speeches/cs20050601/cs20050601.pdf (accessed 22 Oct. 2019).

Beer, A. (2015), 'Structural Adjustment Programmes and Regional Development in Australia', Local Economy, 30(1), pp. 21-40.

Beer, A. (2018) 'The Closure of the Australian Car Manufacturing Industry: Redundancy, Policy and Community Impacts', Australian Geographer, 49(3), pp. 419-438.

Berger-Thomson, L., J. Breusch, and L. Lilley (2018), 'Australia's Experience with Economic Reform', Treasury Working Paper, October. https://treasury.gov.au/ publication/p2018-t332486 (accessed 22 Oct. 2019).

Bingham, F. (2016), Australia's Trade Since Federation. Canberra: Department of Foreign Affairs and Trade. https://dfat.gov.au/about-us/publications/Documents/australiastrade-since-federation.pdf (accessed 22 Oct. 2019).

Bingham, F. (2018), Australia's Foreign Affiliates Trade in Services. Canberra: Department of Foreign Affairs and Trade. https://dfat.gov.au/about-us/publications/Documents/ australias-foreign-affiliates-trade-in-services.pdf (accessed 22 Oct. 2019).

Brennan, G. and J. Pincus (2002), 'Australia's Economic Institutions', in G. Brennan and F.G. Castles (eds.), Australia Reshaped: 200 Years of Institutional Transformation. Cambridge, UK: Cambridge University Press, pp. 53-85.

Campbell, S. and H. Withers (2017), 'Australian Productivity Trends and the Effect of Structural Change', Economic Round-up. https://treasury.gov.au/publication/ p2017-t213722c (accessed 22 Oct. 2019).

Cashin, P. and C.J. McDermott (2002), “"Riding on the Sheep's Back”: Examining Australia's Dependence on Wool Exports' Economic Record, 78, pp. 249-263.

Centre for International Economics (CIE) (2017), Australian Trade Liberalisation: Analysis of Economic Impacts - Final Report. Prepared for Australian Department of Foreign Affairs and Trade. Canberra: CIE. https://dfat.gov.au/about-us/ publications/trade-investment/Pages/cie-report-on-australian-trade-liberalisation.aspx (accessed 22 Oct. 2019).

Corden, W.M. (1996), 'Protection and Liberalization in Australia and Abroad', Australian Economic Review, 29(2), June, pp. 141-154.

Crafts, N. (2018), 'The Productivity Slowdown: Is It the "New Normal”?', Oxford Review of Economic Policy, 34(3), pp. 443-460.

Crook, W. and J. Gordon (2017), 'Rules of Origin: Can the Noodle Bowl of Trade Agreements be Untangled?', Productivity Commission Staff Research Note, Canberra: Productivity Commission. May.

Daley, J. and A. Lancy (2011), Investing in Regions: Making a Difference. Melbourne: Grattan Institute.

Debelle, G. (2017), 'Recent Trends in Australian Capital Flows', Presentation to the Australian Financial Review Banking and Wealth Summit, April.

Department of Foreign Affairs and Trade (DFAT) (2018), 'Australia's Foreign Affiliates Trade in Services'. https://dfat.gov.au/about-us/publications/Documents/australiasforeign-affiliates-trade-in-services.pdf (accessed 22 Oct. 2019). 


\section{Christopher Findlay et al.}

Department of Foreign Affairs and Trade (DFAT) (2019), Composition of Trade Australia 2017-18. https://dfat.gov.au/about-us/publications/Documents/cot2017-18.pdf (accessed 22 Oct. 2019).

Dixon, P.B. (2008), 'Trade Policy in Australia and the Development of Computable General Equilibrium Modelling', Journal of Economic Integration, 23(3), pp. 605-630.

Drysdale, P. (2009), 'APEC: Achievements and Challenges in International Diplomacy', http://www2.jiia.or.jp/kokusaimondai_archive/2000/2009-10_003e.pdf? noprint Accessed (22 Oct. 2019)

Drysdale, P. and C. Findlay (2009), 'Chinese Foreign Direct Investment in Australia: Policy Issues for the Resource Sector', China Economic Journal, 2(2), pp. 133-158.

Ergas, H. and J. Pincus (2016), 'The Wealth of the Nation', in J.R. Nethercote (ed.), Menzies: The Shaping of Modern Australia. Brisbane, Qld, Australia: Connor Court Publishing.

Ferencz, J. (2019), 'The OECD Digital Services Trade Restrictiveness Index', OECD Trade Policy Papers, No. 221. Paris: OECD Publishing.

Findlay, C. (2019), 'Can Cooperation Prevent a Digital Iron Curtain', East Asian Forum Quarterly, 11(3), July-September, pp. 15-18.

Garnaut, R. (1989), Australia and the Northeast Asian Ascendancy: Report to the Prime Minister and Minister for Foreign Affairs and Trade. Canberra: Australian Government Public Service.

Garnaut, R. (2005), 'Breaking the Great Complacency of the Early Twenty First Century', Paper presented at the conference, Sustaining Prosperity, New Reform Opportunities for Australia, 2005 Economic and Social Outlook Conference, Melbourne Institute and The Australian, Melbourne, 31 March.

Garnaut, R. (2013), Dog Days: Australia After the Boom. Collingwood, Vic, Australia: Redback.

Garnaut, R. (2018), 'Plenary Speech at the 2018 Social and Economic Outlook Conference'. https://cpb-apse2.wpmucdn.com/blogs.unimelb.edu.au/dist/a/ 142/files/2016/03/11.10.18-Politicians-Delivering-Change-1ladasg.pdf (accessed 22 Oct. 2019).

Gruen, N. (2009), 'The Contrast Could Not Have Been Greater', in E. Beecher (ed.), Best Australian Political Writing 2009. Melbourne: Melbourne University Publishing. https://www.themandarin.com.au/108619-lessons-from-the-hawkeand-howard-years-of-australian-governance/ (accessed 22 Oct. 2019).

The Guardian (2017), 'Barely Half of Population Born in Australia to Australianborn Parents', 27 June. https://www.theguardian.com/australia-news/2017/ jun $/ 27$ /australia-reaches-tipping-point-with-quarter-of-population-born-overseas (accessed 22 Oct. 2019).

Guttmann, S. and A. Richards (2004), 'Trade Openness: An Australian Perspective', Research Discussion Paper 2004-11, December. Sydney: Economic Group Reserve Bank of Australia.

Hugo, G. (2014), 'Change and Continuity in Australian International Migration Policy', International Migration Review, 48, pp. 868-890.

Kelly, P. (1992), The End of Certainty: The Story of the 1980s. Sydney, NSW, Australia: Allen and Unwin.

Kelly, P. (2000), 'The Politics of Economic Change in Australia in the 1980s and 1990s', RBA Annual Conference Volume. Sydney: Reserve Bank of Australia. 
Kent, C. and J. Simon (2007), 'Productivity Growth: The Effect of Market Regulations', Research Discussion Paper - RDP 2007-04. Sydney: Reserve Bank of Australia.

Koske, I., I.Wanner, R. Bitetti, and O. Barbiero (2015), 'The 2013 Update of the OECD Product Market Regulation Indicators: Policy Insights for OECD and nonOECD Countries', OECD Economics Department Working Papers, No. 1200. Paris: OECD.

Kirchner, S. (2013), 'Time to Dump Australia's Anti-dumping System', Issue Analysis, 141. Sydney:Centre for Independent Studies,.

Kirchner, S. (2018), An Open Door: How Globalised Are the Australian and US Economies. Sydney:The United States Studies Centre, University of Sydney.

Leigh, A. (2013), Battlers and Billionaires: The Story of Inequality in Australia, Melbourne, Vic, Australia: Redback.

Lodefalk, M. (2015). 'Servicification of Manufacturing Firms Makes Divides in Trade Policy-making Antiquated', Working Paper 2015:1. Örebro, Sweden: Örebro University.

Lloyd, P. (2008), '100 Years of Tariff Protection in Australia', Australian Economic History Review, 48, pp. 99-145.

Mann, C.L. (2016), The Twin Challenges of Promoting Productivity and Inclusive Growth. Paris: OECD.

Melitz, M. (2003), 'The Impact of Trade on Intra-industry Reallocations and Aggregate Industry Productivity', Econometrica, 71(6), pp. 1695-1725.

OECD (2016), Back to Work: Australia: Improving the Re-employment Prospects of Displaced Workers. Paris: OECD Publishing.

OECD (2017), 'Australia: Trade and Statistical Note'. http://www.oecd.org/ investment/Australia-trade-investment-statistical-country-note.pdf (accessed 22 Oct. 2019).

OECD (2018a), 'OECD Services Trade Restrictiveness Index (STRI): Australia'. http://www.oecd.org/trade/topics/services-trade/documents/oecd-stricountry-note-australia.pdf (accessed 22 Oct. 2019).

OECD, (2018b), 'Australian Services Trade in the Global Economy', Trade Policy Brief, October. http://australianservicesroundtable.com.au/wp-content/uploads/2018/ 11/Australian-services-trade-in-the-global-economy.pdf (accessed 22 Oct. 2019).

O'Neil, M. (2014) 'Structural Change: Lessons from Port Augusta's Experience in the 1990s'. Economic Issues Paper No. 42, SA Centre for Economic Studies, Adelaide, https://www.adelaide.edu.au/saces/docs/issues-papers/ saces-economic-issues-42.pdf access date 22 October 2019

Parham, D. (2012), 'Australia's Productivity Growth Slump: Signs of Crisis, Adjustment or Both?' Canberra: Productivity Commission.

Parham, D., H. To, N. Ratna, S. Regan, and Q. Grafton (2015), Migration and Productivity in Australia. Canberra: Crawford School of Public Policy, ANU.

Pitcher Partners (2018), 'What Does the New Trans-Pacific Partnership Mean For you?' http://www.pitcher.com.au/news/what-does-new-trans-pacific-partnership-mean-you (accessed 22 Oct. 2019).

Pomfret, R. (2015), 'Reorientation of Trade, Investment and Migration', in S. Ville S. and G. Withers, (eds.), The Cambridge Economic History of Australia, Port Melbounre: Cambridge University Press, pp. 397-418. 
Productivity Commission (2014), 'Australia's Automotive Manufacturing Industry', Inquiry Report No. 70, Productivity Commission, Canberra.

Productivity Commission (2017a), 'Productivity and Income - The Australian Story, Shifting the Dial: 5 Year Productivity Review', Supporting Paper No. 1, Productivity Commission, Canberra.

Productivity Commission (2017b), 'Shifting the Dial: 5 Year Productivity Review', Report No. 84, Productivity Commission, Canberra.

Productivity Commission (2018a), Trade and Assistance Review 2016-2017. Canberra: Productivity Commission.

Productivity Commission (2018b), Rising Inequality? A Stocktake of the Evidence, Commission Research Paper, Productivity Commission, Canberra.

Productivity Commission (2019), PC Productivity Bulletin, May, Productivity Commission, Canberra.

PwC (2018), Free Trade Utilisation Study. PwC. https://www.pwc.com.au/trade/ free-trade-agreement-survey.html (accessed 22 Oct. 2019).

Quinn, M. (2019), 'Keeping Pace with Technological Change: The Role of Capabilities and Dynamism', Speech to the OECD Global Forum on Productivity, Sydney. https://treasury.gov.au/speech/s2019-390085 (accessed 22 Oct. 2019).

Scollay, R., C.C. Findlay, and U. Kaufmann (2011), Australia New Zealand Closer Economic Relations Trade Agreement (ANZCERTA) and Regional Integration. Singapore: Institute of Southeast Asian Studies.

Snape, R.H. (1984), 'Australia's Relations with GATT', Economic Record, 60, pp. 16-27.

Thangavelu, S. and C. Findlay (2018), 'Foreign Investment and Innovation', in J. Drake-Brockman, and P.A. Messerlin (eds.), Potential Benefits of an Australia-EU Free Trade Agreement: Key Issues and Options. Adelaide: University of Adelaide Press, ch.l.

Tuhin, R. and J.A. Swanepoel (2017), 'Export Behaviour and Business Performance: Evidence from Australian Microdata', Department of Industry, Innovation and Science Research Paper 7/2016. https://industry.gov.au/Office-of-the-ChiefEconomist/Research-Papers/Documents/ (accessed 22 Oct. 2019).

UNCTAD (2019), 'Global FDI Continue Their Slide in 2018', Investment Trends Monitor, 31. https://unctad.org/en/PublicationsLibrary/diaeiainf2019dl_en. pdf (accessed 22 Oct. 2019).

Voon, T. and A. Mitchell (2019), 'Australia's Huawei Ban Raises Difficult Questions for the WTO', East Asia Forum, 22 April. https://www.eastasiaforum.org/2019/ 04/22/australias-huawei-ban-raises-difficult-questions-for-the-wto/ (accessed 22 Oct. 2019).

White and Case (2019), 'The CPTPP Enters Into Force: What Does it Mean for Global Trade?' https://www.whitecase.com/publications/alert/cptpp-entersforce-what-does-it-mean-global-trade (accessed 22 Oct. 2019).

Wright, C.F., S. Clibborn, N. Piper, and N. Cini (2016), Economic Migration and Australia in the 21st Century. Sydney, Australia: Lowy Institute.

World Trade Organization (WTO) (2015), Australia. Trade Policy Review. Report by the Secretariat. WT/TPR/S/312, 3 March. Geneva: WTO. 